\title{
Analisis Kemandirian Belajar Matematika dan Peran Keluarga selama Pembelajaran di Era New Normal
}

\author{
Lisa Triana ${ }^{1}$, Sarwo Edy Wibowo ${ }^{2}$, ${ }^{*}$ Wiwin Putriawati ${ }^{3}$ \\ 1,2,3STKIP Paracendekia NW Sumbawa, Nusa Tenggara Barat, Indonesia \\ Email: putriawatiw29@gmail.com \\ Corresponding Author: Wiwin Putriawati
}

\begin{abstract}
Article Info
Article History

Received: 2021-11-20

Revised: 2021-12-15

Published: 2022-01-03

\section{Abstract}

The purpose of this study was to analyze the independence of learning Mathematics and the role of the family during learning in the new normal era. The type of research used is descriptive quantitative research using 12 research subjects. Data collection techniques used documentation and questionnaires. The results of this study are the independence of MTS NW Harapan Jaya Orong Telu students showing $34 \%$ of students

Keywords:

Independence;

Family Role;

New Normal Era. are not yet independent in learning and $66 \%$ of students have been able to learn independently during the new normal. 50\% parents of students play an active role in teaching children's independence and $50 \%$ play a passive role. The results of the correlation test show that there is a relationship between the independence of MTS NW Harapan Jaya Orong Telu students and the role of their parents in teaching them.

Artikel Info
Sejarah Artikel
Diterima: $2021-11-20$
Direvisi: $2021-12-15$
Dipublikasi: $2022-01-03$

Kata kunci: Kemandirian;

Peran Keluarga;

Era New Normal.

Abstrak

Tujuan dari penelitian ini adalah untuk menganalisis kemandirian belajar Matematika dan peran keluarga selama pembelajaran di era new normal. Jenis penelitian yang digunakan adalah penelitian deskriptif kuantitatif dengan menggunakan 12 subjek penelitian. Teknik pengumpulan data yang digunakan dokumentasi dan angket. Hasil pada penelitian ini adalah kemandirian siswa MTS NW Harapan Jaya Orong Telu menunjukkan 34\% siswa belum mandiri dalam belajar dan 66\% siswa telah mampu belajar mandiri selama new normal. 50\% orang tua siswa berperan aktif dalam mengajar kemandirian anak dan $50 \%$ berperan secara pasif. Hasil uji korelasi menunjukkan ada hubungan kemandirian siswa MTS NW Harapan Jaya Orong Telu dengan peran orang tuanya dalam mengajar mereka.
\end{abstract}

\section{PENDAHULUAN}

Kemandirian berasal dari kata mandiri yang berarti berdiri sendiri, yaitu suatu keadaan untuk mengatur seseorang dan mengarahkan diri sesuai tingkat perkembangannya. Kemandirian belajar adalah proses belajar yang terjadi dalam diri sesorang, dan untuk mencapai tujuan belajar orang tersebut dituntut untuk secara aktif tidak bergantung kepada orang lain, termasuk tidak tergantung pada gurunya (Basir, 2010). Pencapaian prestasi belajar disebabkan oleh banyak hal, hal tersebut diantaranya adalah cara belajar, minat, motivasi, kelelahan, dukungan keluarga, serta teman bergaul. Diungkapkan oleh Slameto (2010), bahwa terdapat dua faktor yang mempengaruhi prestasi belajar meliputi faktor internal dan eskternal. Faktor internal adalah faktor yang ada dalam diri individu meliputi kesehatan, kecerdasan, cara belajar, bakat, minat, motivasi, serta kelelahan. Sedangkan faktor eksternal adalah faktor yang berasal dari luar individu meliputi faktor lingkungan keluarga, lingkungan sekolah, dan lingkungan masyarakat. Salah satu cara belajar yang dimaksud adalah tingkat kesadaran anak dalam belajar. Tingkat kesadaran belajar atau yang biasanya disebut dengan kemandirian belajar. Menurut Suhendri (2012), kemandirian belajar adalah suatu aktivitas belajar siswa yang dilakukan tanpa bergantungan kepada orang lain baik teman maupun gurunya dalam mencapai tujuan belajar yaitu menguasai materi atau pengetahuan dengan baik dengan kesadarannya sendiri serta dapat mengaplikasikan pengetahuan dalam menyelesaikan masalah-masalah dalam kehidupan sehari-hari. Kemandirian belajar ini dinilai sangat berpengaruh karena kebanyakan siswa hanya belajar ketika ada tugas sekolah yang diberikan guru dan ketika ada ulangan saja. Hal ini menunjukan masih rendahnya kesadaran dalam belajar, sehingga menyebabkan pencapaian prestasi belajar. Fenomena yang banyak terjadi dikalangan remaja, baik peserta didik dan mahasiswa adalah mereka belum mampu mandiri dalam belajar hal ini dikarenakan 5 oleh beberapa kebiasaan negatif, seperti belajar hanya menjelang ujian, membolos, menyontek, dan mencari bocoran soal-soal ujian. Menurut Pratiwi, dan Laksamiwati (2016), adanya fenomena tersebut menimbulkan gangguan mental 
yang akan berkelanjutan. Kemandirian belajar sendiri sangatlah diperlukan dalam sistem pendidikan tinggi, karena akan membantu invidu untuk belajar aktif. Menurut Huda, et al., (2019), kemandirian yang dipadukan dengan keaktifan peserta didik untuk menunjang proses pembelajaran sangatlah bergantung pada kondisi seperti di era new normal saat ini. Perkemba-ngan zaman menuntut setiap individu untuk mampu berkembang mengikuti perubahan, salah satunya dibidang pendidikan, sehingga perkem-bangan teknologi didukung dengan adanya smartphone dibandingkan dengan media belajar seperti buku teks atau lainnya. Mengingat pentingnya peranan orang tua dalam mendidik anak beberapa penelitian telah membuktikan bahwa orang tua memiliki peran yang sangat besar dalam kemampuan anak dalam lingkup pendidikan. Salah satunya penelitian yang dilakukan oleh Valeza, (2017) dimana penelitian ini menunjukan peran orang tua dalam menentukan hasil belajar siswa sangatlah besar. Orang tua yang selalu memberikan perhatian pada anaknya, selalu memberikan motivasi pada anaknya, terutama perhatian pada kegiatan belajar dirumah.

Dengan motivasi dari orang tua sehingga hasil belajar atau prestasi yang diraih oleh siswa menjadi lebih baik. Berdasarkan berbagai teori tersebut, kemandirian belajar ditunjukkan dengan adanya kemampuan untuk menyelesaikan masalah yang dihadapi dengan adanya perubahan tingkah laku. Adanya perubahan tingkah laku, membuat anak mengalami peningkatan dalam berpikir, belajar untuk bisa mandiri tanpa mengandalkan bantuan dari orang lain dan mampu bertanggung jawab untuk mengerjakan tugas tanpa harus melibatkan orang lain. Mereka tidak mudah terpengaruh oleh orang lain mengenai proses belajarnya. Mereka akan berusaha semaksimal untuk menyelesaikan permasalahan sendiri tanpa bantuan orang lain. Berdasarkan hasil observasi maka penulis dapat melihat ketergantungan siswa kepada guru, dalam menyelesaikan soal atau latihan, siswa memiliki ketergantungan yang sangat tinggi kepada guru. Pada proses pembelajaran adanya ketergantungan dan kurangnya inisiatif sendiri membuat siswa kurang mandiri dalam belajar, dikarenakan siswa masih sering bermain sehingga, kemandirian untuk belajar masih kurang. Dari hasil observasi penulis tertarik melakukan penelitian ditempat tersebut. Berdasarkan latar belakang yang telah dijelaskan diatas, penulis bermaksud untuk mengadakan penelitian tentang "Analisis Kemandirian Belajar Matematika Dan Peran
Keluarga Selama Pembelajaran di Era New Normal".

\section{METODE PENELITIAN}

Sesuai dengan permasalahan yang akan diteliti, Jenis penelitian ini termasuk mengungkapkan secara mendalam Analisis Kemandirian Belajar Matematika dan Peran Keluarga Selama Pembelajaran di Era new normal. Penelitian ini dilaksanakan di MTS NW Harapan Jaya Tepatnya Didesa Harapan Jaya Yang Beralamat Dikecamatan Orong Telu. Alasan peneliti memilih sekolah tersebut untuk dijadikan tempat penelitian untuk mengetahui tingkat kemandirian siswa, berikut ini detail waktu dan pelaksanaan materi.

Tabel 1. Waktu Pelaksanaan Penelitian

\begin{tabular}{|c|c|c|c|}
\hline $\begin{array}{c}\text { Pertemua } \\
\text { Ke- }\end{array}$ & $\begin{array}{c}\text { Hari dan } \\
\text { Tanggal } \\
\end{array}$ & Waktu & Materi \\
\hline 1 & $\begin{array}{l}\text { Senin, } 12 \\
\text { Juli } 2021 \\
\end{array}$ & $\begin{array}{c}08.30- \\
10.00 \\
\end{array}$ & $\begin{array}{l}\text { Menjelaskan tentang } \\
\text { kemandirian siswa }\end{array}$ \\
\hline 2 & $\begin{array}{l}\text { Rabu, } 14 \\
\text { Juli } 2021\end{array}$ & $\begin{array}{l}9.00- \\
10.30\end{array}$ & $\begin{array}{l}\text { Penyebaran angket } \\
\text { sekaligus pengisian } \\
\text { angket }\end{array}$ \\
\hline
\end{tabular}

Subjek dalam penelitian ini sebanyak 12 siswa serta orang tuanya. Subjek penelitian dipilih menggunakan metode purposive sampling. Sedangkan objek penelitiannya adalah kemandirian belajar matematika dan peran keluarga selama pembelajaran di era new normal, adapun Teknik Pengumpulan Data yang digunakan dalam penelitian ini diantaranya:

1. Dokumentasi

Dokumentasi yaitu mencari data mengenai variabel yang berupa catatan, transkrip, buku, surat kabar, majalah, prasasti, notulen rapat, agenda dan sebagainya.

2. Angket

Angket yaitu untuk mengetahui kemandirian belajar siswa dengan memberikan pernyataan tertulis kepada responden yang telah disiapkan. Penyebaran dan pengumpulan angket kemandirian belajar dilaksanakan pada hari rabu, 14 juli 2021 tepatnya pada jam 9.00 $10.30 \mathrm{~s} / \mathrm{d}$ bertempat didalam kelas. Kemudian pengumpulan data oleh peneliti dapat dilaksanakan selama 80 menit untuk mengetahui kemandirian belajar siswa. Pengambilan data sebanyak 12 siswa kelas VIII (Delapan) MTS NW Harapan Jaya di Kec. Orong Telu.

Tabel 2. Instrumen Angket

\begin{tabular}{ccc}
\hline Variabel & Indikator & Pengukuran \\
\hline & $\begin{array}{l}\text { 1. Ketidak bergantungan } \\
\text { dengan orang lain }\end{array}$ & Skala \\
Kemandiri & $\begin{array}{l}\text { Memiliki kepercayaan } \\
\text { an Belajar }\end{array}$ & $\begin{array}{l}\text { Guttman } \\
\text { diri }\end{array}$ \\
& Ya=1) \\
\hline
\end{tabular}


3. Berperilaku disiplin

4. Memiliki rasa tanggung jawab

5. Berperilaku berdasarakan inisiatif sendiri

\begin{tabular}{lll}
\hline \multirow{2}{*}{ Peran } & 1. Pendidik & Skala \\
Orang Tua & 2. Motivator & Guttman \\
& 3. Fasilitator & $($ Ya=1) \\
& & $($ Tidak=0) \\
\hline
\end{tabular}

Indikator penilaian Angket Kemandirian Belajar Mandiri : Apabila jawaban responden di atas $>50 \%$

Tidak Mandiri : Apabila jawaban responden di bawah $>50 \%$

Indikator penilaian Angket Peran Orang Tua yang Berperan Aktif $=$ Apabila jawaban responden di atas $>50 \%$

Tidak Berperan Aktif: Apabila jawabam responden di bawah $>50 \%$

Data dianalisis secara deskriktif kuantitatif. Dalam menghitung persentase jawaban angket responden digunakan rumus berikut ini:

$$
\mathrm{p}=\mathrm{f} / \mathrm{n} \times 100
$$

Keterangan:

$\mathrm{p}=$ Persentase

$\mathrm{f} \quad=$ Jumlah skor yang diperoleh

$\mathrm{n}=$ Maksimal skor

Milles and Huberman dalam Sugiyono (2013), mengemukakan bahwa aktivitas dalam analisis data, yaitu data reduction, data display, dan conclision drawing/verification.

1. Data reduction (reduksi data)

Reduksi data adalah proses penggabu-ngan dan penyeragaman segala bentuk data yang didapatkan menjadi satu bentuk tulisan yang akan dianalisis. Dalam penelitian ini, akan ditulis hasil angket, dan wawancara sesuai format data masingmasing.

2. Data display (penyajian data)

Dalam penelitian ini, peneliti menyajikan data tentang kemandirian dalam pembelajaran dalam bentuk yang bersifat deskriptif. Peneliti mengumpulkan informasi kemudian peneliti menganalisis data yang sudah didapatkan sehingga dilanjutkan dengan penarikan kesimpu-lan.

3. Conclusion drawing/verification (penarikan kesimpulan)

Penarikan kesimpulan adalah usaha untuk mencari, menguji, mengecek kemb-ali dan memahami makna atau arti, keteraturan, pola-pola, penjelasan, alur dan sebab- akibat. Peneliti melakukan kesimpulan dengan melihat hasil reduksi dan menganalisis data yang sudah didapat, kemudian peneliti melakukan kesimpulan kemandirian belajar dan peran keluarga dalam pembelajaran.

\section{HASIL DAN PEMBAHASAN}

A. Hasil Penelitian

Penelitian ini memfokuskan pada analisis kemandirian belajar matematika dan peran keluarga selama pembelajaran di era new normal. Jumlah responden yang teliti berjumlah 12 orang yang diambil dari kelas VIII di MTS NW Orong Telu desa Harapan Jaya. Responden yang diteliti terbagi atas 8 siswa perempuan dan 4 siswa laki-laki. Dalam hal ini sekolah yang diteliti yaitu MTS NW Harapan Jaya yang beralamat di Kec. Orong Telu, Berikut disajikan data Karakteristik Responden yang menjadi sampel penelitian.

Tabel 3. Identitas Responden

\begin{tabular}{ccc}
\hline Jenis Kelamin & Jumlah & Persen\% \\
\hline Laki-Laki & 4 & $34 \%$ \\
\hline Perempuan & 8 & $66 \%$ \\
\hline Total & 12 & $100 \%$ \\
\hline
\end{tabular}

Berdasarkan identitas responden jenis kelamin responden dalam penelitian ini didominasi oleh jenis kelamin perempuan responden $(66 \%)$ dan sisanya berjenis lakilaki responden (34\%), Analisis Kemandirian Belajar Siswa Secara umum jika dilihat dari keseluruhan indikator kemandirian siswa dapat dikatakan bahwa tingkat kemandirian siswa dan peran keluarga selama pembelajaran di era new normal terdapat hasilnya pada tabel berikut.

Tabel. 4 Persentase Kemandirian Siswa

\begin{tabular}{ccc}
\hline Kategori & Jumlah & Persen $\%$ \\
\hline Mandiri & 3 & $34 \%$ \\
\hline Tidak Mandiri & 9 & $66 \%$ \\
\hline Total & 12 & $100 \%$ \\
\hline
\end{tabular}

Berdasarkan persentase kemandirian siswa didapatkan hasil bahwa siswa dengan kemandirian belajar dengan kategori tidak mandiri sebanyak 4 siswa, dan siswa mandiri sebanyak 8 siswa. Subjek dalam penelitian ini diambil 3 (tiga) orang yaitu 2 orang orang siswa dan satu orang tua untuk mengetahui kemandirian belajar matematika dan peran keluarga selama pembelajaran di Era New Normal. 
Empat siswa yang kemandirian belajar masih rendah artinya bahwa siswa tersebut belum sepenuhnya mempunyai sikap kemandirian dalam belajar, hal ini dikarenakan kurangnya kesempatan, dukungan dan dorongan dari keluarga dan lingkungan sekitar. sedangkan siswa yang memiliki kemandirian sangat tinggi. Jadi seorang siswa yang memiliki tingkat kemandirian belajar yang sangat tinggi dapat dikatakan bahwa siswa mampu mengatur dan mengendalikan kegiatan belajarnya. Atas dasar pertimbagan dan tanggung jawab sendiri dan akhirnya akan memngaruhi hasil belajar

Tabel 5. Persentase Peran Orang Tua

\begin{tabular}{ccc}
\hline Kategori & Jumlah & Persen\% \\
\hline Peran Pasif & 6 & $50 \%$ \\
\hline Peran Aktif & 6 & $50 \%$ \\
\hline Jumlah & 12 & $100 \%$ \\
\hline
\end{tabular}

Menurut hasil persentase peran keluarga mendapat respon yang di kategori peran pasif sebanyak 6 orang sedangkan yang peran aktif mendapat respon sebanyak 6 orang. Akan tetapi, pada persentase tersebut tidak terdapat perbedaan yang cukup signifikasikan yang berarti peran keluarga yang cukup baik.

\section{B. Pembahasan}

Mengingat pentingnya peranan orang tua dalam mendidik anak beberapa penelitian telah membuktikan bahwa orang tua memiliki peran yang sangat besar dalam kemampuan anak dalam lingkup pendidikan. Dimana penelitian ini menunjukan peran orang tua dalam menentukan hasil belajar siswa sangatlah besar. Orang tua yang selalu memberikan perhatian pada anaknya, selalu memberikan motivasi pada anaknya, terutama perhatian pada kegiatan belajar dirumah. Dengan motivasi dari orang tua sehingga hasil belajar atau prestasi yang diraih oleh siswa menjadi lebih baik.

Kemandirian merupakan suatu sikap yang diperoleh secara komulatif melalui proses yang dialami seseorang dalam perkembangannya. Dimana dalam proses menuju kemandirian individu belajar untuk menghadapi berbagai situasi dalam lingkungan sosialnya sampai ia mampu berpikir dan mengambil tindakan yang tepat dalam mengatasi setiap situasi. Aktivitas bersama membantu anak untuk menanamkan cara berpikir dan bersikap dimasyarakat dan menjadikan sebagai caranya sendiri. Orang dewasa (teman sebaya yang lebih tua) seharusnya membantu mengarahkan dan mengordinasikan proses pembelajaran anak sehingga anak mampu menguasai secara mandiri.

Jadi keadaan mandiri akan muncul bila seseorang belajar, sebaliknya kemandirian tidak muncul apabila siswa tidak dibekali dengan ilmu yang cukup. Menurut purwanto (2014), hasil belajar dapat dipahami dengan melihat dua kata yang membentuknya yaitu hasil dan belajar. Hasil diartikan sebagai sebuah perolehan yang didapatkan karena suatu aktivitas yang dilakukan atau perubahan melalui suatu proses. Sedangkan belajar merupakan usaha yang dilakukan untuk mendapatkan perubahan tingkah laku. Perubahan perilaku itu yang disebut dengan hasil belajar.

Dari analisis data yang diketahui terdapat $33 \%$ siswa MTS NW Orongyang tidak mandiri belajar selama new normal dan sisanya $66 \%$ mampu belajar secara mandiri. 34\% siswa belum sepenuhnya mempunyai sikap kemandirian dalam belajar, hal ini dikarenakan kurangnya kesempatan, dukungan dan dorongan dari keluarga dan lingkungan sekitar terutama saat new normal beberapa siswa perlu bimbingan langsng untuk beradaptasi dalam belajar. Sedangkan siswa yang memiliki tingkat kemandirian belajar yang sangat tinggi dapat dikatakan bahwa siswa mampu mengatur dan mengendalikan kegiatan belajarnya. Atas dasar pertimbagan dan tanggung jawab sendiri dan akhirnya akan memngaruhi hasil belajar.

Jika dilihat dari hasil angket peran orang tua siswa terlihat $50 \%$ yang berperan aktif dan $50 \%$ pasif. Bagi yang berperan aktif adalah mereka orang tua yang masih bingung harus bersikap seperi apa dalam menanggapi kebijakan new normal untuk bidang pendidikan anak. Sehingga orang tua hanya terlihat acuh dalam pembelajaran anak khususnya saat new normal. Hasil uji korelasi menunjukkan terdapat hubungan kemandirian anak dalam belajar dengan peran orang tua. Temuan ini sejalan dengan teori yang dikemukakan oleh Novantri \& Afrianti (2020) bahwa usaha yang dapat dilakukan agar siswa memiliki sikap kemandirian yang tinggi yaitu hendaknya orang tua mengajarkan kemandirian dari sejak dini pada anak sesuai kemampuannya, memberikan kesempatan pada anak agar dapat mengembangkan kemampuan yang dimilikinya hal ini sesuai dengan belajar mengambil inisiatif, dan belajar bertanggung 
jawab dengan apa yang dilakukan. Selain itu sekolah juga dapat memberikan latihan atau tugas-tugas sehingga siswa dapat belajar secara mandiri sehingga terbentuklah kemandirian dalam diri siswa. Jika kemandirian dimiliki oleh setiap siswa maka dengan mudah pencapaian hasil belajar tinggi.

Mengingat pentingnya peranan orang tua dalam mendidik anak beberapa penelitian telah membuktikan bahwa orang tua memiliki peran yang sangat besar dalam kemampuan anak dalam lingkup pendidikan. Salah satunya penelitian yang dilakukan oleh Valeza, (2017) dimana penelitian ini menunjukan peran orang tua dalam menentukan hasil belajar siswa sangatlah besar. Orang tua yang selalu memberikan perhatian pada anaknya, selalu memberikan motivasi pada anaknya, terutama perhatian pada kegiatan belajar di rumah. Dengan motivasi dari orang tua sehingga hasil belajar atau prestasi yang diraih oleh siswa menjadi lebih baik.

Hasil penelitian ini sejalan dengan hasil penelitian Melida Fitroturrohmah (2019) bahwa peran orang tua memberi sumbangan sebesar $63,32 \%$ pada prestasi belajar dan pada ranah kognitif dan 30,25\% pada ranah psikomotor. Dari penelitian ini mendukung temuan penulis bahwa ada hubungan yang signifikan antara kemandirian anak dalam belajar dengan peran orang tua dalam mendidik anaknya.

\section{SIMPULAN DAN SARAN}

\section{A. Simpulan}

Kesimpulan pada penelitian ini adalah kemandirin siswa MTS NW Harapan Jaya Orong Telu menunjukkan 34\% siswa belum mandiri dalam belajar dan $66 \%$ siswa telah mampu belajar mandiri selama new normal. $50 \%$ orang tua berperan aktif dalam mengajar kemandirian anak dan $50 \%$ orang tua berperan secara pasif. Hasil uji korelasi menunjukkan ada hubungan kemandirian siswa MTS NW Harapan Jaya Orong Telu dengan peran orang tuanya dalam mengajar mereka.

\section{B. Saran}

Adapun saran yang dapat disampaikan berdasarkan hasil penelitian ini yaitu: (1) diharapkan para siswa dapat meningkatkan kemandirian belajar yang baik sehingga hasil belajar siswa tetap meningkat, (2) Orang tua, hendaknya selalu memperhatikan dan menin- gkatkan kemandirian belajar guna memperoleh hasil yang baik. Upaya tersebut dapat dilakukan dengan memperhatikan aspekaspek atau indikator kemandirian belajar yang mempengaruhi hasil belajar, khususnya pada mata pelajaran Matematika, (3) Peneliti selanjutnya dapat meningatkan kemandirian belajar dan peran keluarga dalam pembelajaran di era new normal.

\section{DAFTAR RUJUKAN}

Amalia, A., Syafitri, ., L. F., Sari, V. T. A., \& Rohaeti, E. E. 2018. Hubungan Antara Kemampuan Pemecahahan Masalah Matematika Dengan Self Efficacy Dan Kemandirian Belajar Siswa SMP. Jurnal pembelajaran matematika inovatif, 1(5), 887-894.

Basir, L. O. 2010. Kemandirian Belajar atau Belajar Mandiri. http://www.smadwiwarna.net/website/ data/artikel/kemandirian.htm. Diakes 20 $\underline{12-2015}$.

Deny Diniyati. 2012. Meningkatkan Minat, Kemandirian Dan Prestasi Belajar Siswa Pada Pelajaran Matematika Melalui Pembelajaran Kooperatif Tipe Think Pair Share (TPS). Skripsi tidak diterbitkan, Universitas Muhammadiyah Purwokerto.

Huda, M. N., Mulyono, M., Rosyida, I., \& Wardono, W. 2019. Kemandirian belajar berbantuan mobile learning. PRISMA: Prosiding Seminar Nasional Matematika, 198-806. Retrieved from https://journal.unnes.ac,id/sju/index.php/ prisma/article/view/29270.

Ibrahim. 2012. Evaluasi Pembelajaran. Jakarta: Rhineka Cipta.

Melida Fitroturrohmah. 2019. Hubungan Peran Orang Tua Dengan Prestasi Belajar Siswa Kelas Tinggi SDN Kedung 01 Jepara. JANACITTA Journal of Primary and CHildren's Education.Vol 2, No 2.

Novantri, W., \& Aftriyati, L. W. 2020. Are Discovery Learning And Indipendent Learning Efective In Improving Students'cognitive Skill? Belajar Efektif Dalam Meningkatkan Kemampuan. Indonesia journal of science and mathematic Education, 03 (july), 144- 
152,https:?//doi.org/10.2404.ijsme.v312. 6615.

Pratiwi, I. D., \& Laksmiwati, H .2016. Kepercayaan diri dan kemandirian belajar pada siswa SMA Negeri X. Jurnal Psikologi Teori dan Terapan, 7 (1), 43-49. DOI: 10.26740/jptt.v7n1.p43-4

Rafika Israwati dan Bachtiar. 2017. Upaya Guru Dalam Menumbuhkan Kemandirian Belajar Siswa Di SD Negeri 22 Banda Aceh, Jurnal Ilmiah Pendidikan Guru Sekolah Dasar FKIP Unsyiah Volume 2 Nomor 1, 115-123 Februari 2017, (Http://media.neliti.com/)

Slameto. 2010. Belajar dan faktor-faktoryang Mempengaruhinya. Jakarta: Rineka Cipta.

Sudjana. 2004. Dasar-dasar Proses Belajar Mengajar. Bandung: Sinar Baru Setiawati. 2002. Optimalsasi Kegiatan Belajar Mengajar. Bandung: PT. Remaja Rosdakarya.
Suhendri, Huri. 2012. "Pengaruh Kecerdasan Matematika-Logi, Rasa Percaya Diri, dan Kemendirian Belajar terhadap Hasil Belajar Matematika". Jurnal Formatif 1 (1): 29-39. Universitas Indraprasa PGRI.

Sumarno. 2002. Kemandiran Belajar: Apa, Mengapa, Dan Belajar Dikembangkan pada Peserta Didik. Jurnal. UPI.

Sulo, L. 2005. Pengantar Pendidikan. Jakarta: PT Rineka Cipta. Saroni, M. 2006. Manajemen Sekolah. Yogyakarta: Ar-Ruzz Media.

Suryabrata, Sumadi. 2004. Psikologi Pendidikan. Yogyakarta: Andi Offset.

Valeza, Alsi R. 2017. Peran Orang Tua dalam Meningkatkan Prestasi Anak di Perum Tanjung Raya Permasi Kelurahan Pematang Wangi Kecamatan Tanjung Senang Lampung. Skripsi: UIN Raden Intan Lampung. 